\footnotetext{
${ }^{1}$ Department of Animal Science, Faculty of Agriculture, Chiang Mai University, Thailand

${ }^{2}$ Institute of Animal Breeding and Husbandry, Georg-August-University of Göttingen, Germany
}

\title{
Carcass and meat characteristics of male chickens between Thai indigenous compared with improved layer breeds and their crossbred
}

\begin{abstract}
The study of carcass and meat quality of four male genotypes namely: Thai native (TH), crossbred (Thai native $x$ Barred Plymouth Rock; THB), Barred Plymouth Rock (BPR) and Shanghai (SH) chickens was conducted. Three hundred and twenty birds receiving from four equal groups were allotted in Completely Randomized Design (CRD). They were fed from one day and slaughtered at 16 weeks of age. Breast (M. pectoralis major) and thigh (M. biceps femoris) muscles were investigated for meat quality. TH had lower slaughtered weight $(\mathrm{P}<0.001)$ but higher lean : bone as well as less bone percentage $(\mathrm{P}<0.05)$ than all groups. Thigh muscle fiber of TH had higher type I and lower type IIB whereas there were similar in breast muscle fiber. Meat quality in terms of IMF, cholesterol and triglyceride contents as well as n-3 fatty acid and the ratio of n-6/n-3 of Thai indigenous male strain was more favorable compared to those all genotypes. Breast and thigh muscle were higher in shear force value and collagen content but the sensory evaluation was not significantly different. Since they were similar in sensory evaluation, the male layer and the male crossbred chickens have the potential to substitute TH in a market serving consumers who prefer chewy chicken meat.
\end{abstract}

Keywords: indigenous chicken, male layer, muscle, carcass, eating quality

\section{Zusammenfassung}

Titel der Arbeit: Schlachtkörperzusammensetzung und Fleischqualität nativer thailändischer Masthühner und deren Kreuzungen

Die Untersuchungen der Schlachtkörper- und Fleischqualität erfolgte mit vier Genotypen: Thai native (TH), der Kreuzung (Thai native x Barred Plymouth Rock; THB), Barred Plymouth Rock (BPR) sowie der Herkunft Shanghai (SH). Die Probanden wurden aus einem kompletten randomisierten Design (n=320) zufällig ausgewählt und mit 16 Wochen geschlachtet. Sowohl an der Brust (Pectoralis major) als auch an der Keule (M. biceps femoris) wurde die Fleischqualität untersucht. Die Herkunft TH hatte ein niedrigeres Schlachtgewicht $(\mathrm{P}<0,001)$ bei einem höheren Fleisch : Knochen-Verhältnis sowie einen geringeren Knochenanteil $(\mathrm{P}<0,05)$ gegenüber allen anderen Gruppen. In der Keulenmuskulatur wies die Herkunft TH einen höheren Anteil an Typ I Muskelfasern und weniger Typ IIB Fasern auf. In den Muskelfasern der Brust bestanden keine Unterschiede zwischen den Herkünften. Die Fleischbeschaffenheit war bei der TH Herkunft in Form von IMF, Cholesterol und Triglyceridgehalt sowie n-3 Fettsäuren und dem n-6/n-3 Verhältnis im Vergleich zu den anderen Herkünften am günstigsten. Demgegenüber waren die Scherkraftwerte und der Kollagengehalt in Brust und Keule bei TH höher, jedoch bestanden im sensorischen Gesamteindruck keine signifikanten Unterschiede. Da die Unterschiede insgesamt relativ gering sind, besitzen die geprüften Herkünfte das Potenzial, Konsumentenwünsche nach weniger fettem aber saftigem Fleisch zu befriedigen.

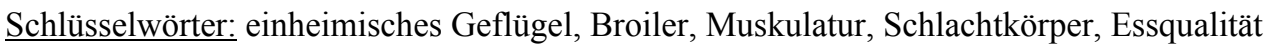

\section{Introduction}

Poultry or 'white meat' is an alternative meat for health conscious consumers, as it contains low cholesterol and fat. However, consumers in Thailand prefer indigenous chicken meat to poultry meat because indigenous chicken meat has more chewy and tasty meat (JATURASITHA et al., 2002). Thai indigenous chicken has a very poor 
growth rate and feed efficiency; therefore it takes about 4 months to meet the market weight at $1.5 \mathrm{~kg}$ (LEOTHARAKUL et al., 2002). This is 2.5 times less efficient than poultry but the farmers are satisfied because the price of Thai indigenous chicken is high. To serve this demand, male hen is alternative. In layer industry, male hen is unfavorable from the hatchery; therefore it would be reared for meat production. Meat from hen was rougher in texture and tougher than those of female and castrate hen (JACOB and MATHER, 2000).

An advantage of a leaner carcass is a desirable composition of poultry carcass including the portion of retail cuts. Poultry carcass composition is mainly affected by breed (SHAHIN and ELAZEEM, 2005; JATURASITHA et al., 2004a and 2008) and feeding systems (PETER et al., 1997). These two main factors have also shown to influence the meat quality. Eating quality is the most important aspect of meat acceptability which can be defined both in physiochemical term i.e. $\mathrm{pH}$-, conductivity (EC) values as well as direct meat traits in terms of sensory evaluation, water holding capacity and in chemical composition. Muscle fibers in terms of types and size are associated with meat quality (KLONT et al., 1998). In poultry meat, meat quality of breast and thigh meat is important (ANDRASSY-BAKA et al., 2003).

The objective of this study was to compare carcass and meat quality traits as well as muscle fiber characteristics in Thai indigenous male chicken to male laying hen (Bar Plymouth Rock and Shanghai) as well as the male crossbred between Thai indigenous and Bar Plymouth Rock chicken in order to provide data for the evaluation of various aspects of Thai indigenous male chicken and male layer production to assure the opportunity for commercial/industrial scale production.

\section{Material and methods}

\section{Sample collection and measurements at the abattoir}

The study of carcass and meat characteristics of Thai indigenous male chicken and male layer raised in Thailand was conducted in a completely randomized design (CRD) (STEEL and TERRIE, 1980). This experiment was approved by the Animal Care and Use Committee of Livestock Department following the Guidelines of Federation of Animal Science Societies (1999). The treatments were genotypes (Thai native [TH], Thai native x Bar Plymouth Rock [THB], Bar Plymouth Rock [BPR] and Shanghai $[\mathrm{SH}]$ chickens). There were 80 birds of each genotype within 10 replications per group per pen distributed across genotypes. A total of 320 chickens were raised from 1 day to 16 weeks of age at commercial farm, Chiang Mai (Thailand) with ad libitum feed according to NRC (1994). Sixty chickens of each genotype (8 or 7 birds per sub group) were slaughtered by manual neck cut, bled for $2 \mathrm{~min}$, scalded at $60{ }^{\circ} \mathrm{C}$ for $2 \mathrm{~min}$, plucked in a rotary drum picker for $30 \mathrm{~s}$, and eviscerated according to JATURASITHA (2004). After chilling for $24 \mathrm{~h}$, all carcasses were dressed in Thai (boneless) (JATURASITHA, 2004) and international cutting style (HENRICKSON, 1978). In all carcasses, conductivity value (EC) (Model WTW, Germany) and $\mathrm{pH}$ value (Model 191, Knick, Berlin, Germany) were measured at 45 min and 24 h p.m. Meat (breast and thigh) color were evaluated at $48 \mathrm{~h}$ with Minolta Chroma meter (Model CR-300, Minolta camera Co. LTD, Osaka, Japan) to record lightness, redness and yellowness $\left(\mathrm{L}^{*}, \mathrm{a}^{*}\right.$ and $\left.\mathrm{b}^{*}\right)$, respectively according to JATURASITHA (2000). 


\section{Laboratory analyses}

After chilling the carcass for $24 \mathrm{~h}$ at $4{ }^{\circ} \mathrm{C}$, breast (M. pectoralis major) and thigh $(M$. biceps femoris) muscles were collected in order to evaluate meat quality characteristics and kept at $-20{ }^{\circ} \mathrm{C}$ until being analyzed. Water holding capacity (WHC) was determined as drip (HONIKEL, 1987) thawing and cooking losses (either boiled in a water bath in sealed bags or grilled in convector oven until internal temperature of about $80{ }^{\circ} \mathrm{C}$ ).

Histological samples of breast and thigh muscle were taken from the center of the ventral side of these muscles. Serial cross-sections (10 $\mu \mathrm{m}$ thick) were cut and stained for combined ATPase/NADH diaphorase (modified after HORAK, 1983). Density of the histochemical reaction product in the ATPase/NADH diaphorase staining was determined for each fiber. By using three density classes for ATPase, three possible different fiber types can theoretically be identified using an image analyzer (LUCIA, Japan). Fibers were classified as type I, II A and II B (BROOKE and KAISER, 1970). The percentage of each fiber type (expressed in number and in area percentage) was determined and the cross sectional area $(\mu \mathrm{m})$ of individual myofiber was measured (KLONT et al., 1998).

Homogenised uncooked breast and thigh muscle were analysed for the contents of moisture, protein and fat percentage as outlined by AOAC (1995). Collagen determinations were performed by a three-step procedure combining separation as described by HILL (1966) as well as hydrolysis and UV detection as suggested by BERGMAN and LOXLEY (1963). In the separation step, homogenization was performed for $1 \mathrm{~min}$ at $10.000 \mathrm{rpm}$ with a Polytron PT 1200B (Kinematic AG, Littau, Switzerland). Contents of soluble and insoluble collagen were determined separated as hydroxyproline at $558 \mathrm{~nm}$ wavelength with a Spectrophotometer (Gynesys, Spectronic Instruments Inc., New York, USA).

Cholesterol concentrations were determined in both muscles after extraction of the fat from the tissue according to FOLCH et al. (1957). The extracted fat was saponified as described by ABELL et al. (1951) in order to eliminate triglycerides. In the extracted and saponified fat total cholesterol was determined in the residual extract according to JUNG et al. (1975). In the extracted but not saponified fat from the tissues also triglyceride contents were measured as outlined by BIGGS et al. (1975). Thiobarbituric acid reaction substance (TBARS) was analyzed as malondialdehyde concentrations in intramuscular fat as recommended by ROSSELL (1994).

Shear force of boiled breast muscle was determined in six $1.27 \mathrm{~cm}$ diameters cores using a Warner-Bratzler shear device attached to an Instron universal testing machine (model 5565, Instron Ltd., Buckinghamshire, UK). A crosshead speed of $200 \mathrm{~mm} / \mathrm{min}$ and a $5 \mathrm{kN}$ load cell calibrated to read over range of $0-100 \mathrm{~N}$ were applied. Breast and thigh muscle were evaluated by a sensory panel with sensory evaluation training following the methods of AMERINE et al. (1965). It was roasted in a convector oven at $180{ }^{\circ} \mathrm{C}$ until the internal temperature reached $80{ }^{\circ} \mathrm{C}$ then cut into small pieces at $1 \times 1 \mathrm{~cm}$. Six trained panelists judged samples twice a week and each time they evaluated eight samples. Panelists were asked to grade meat quality in terms of tenderness, juiciness, flavour and overall acceptability on a 1-9 point scale (with $1=$ very unfavourable and $9=$ very favourable).

The fatty acid profile of breast and thigh muscle was analyzed by the method of FOLCH et al. (1957). Fat was extracted by chloroform and methanol (2:1v/v). Methyl esters were prepared by the method of MORRISON and SMITH (1964). Fatty acids 
were analyzed by gas chromatography (model GC-2010, Shimadzu, Tokyo, Japan) equipped with a $0.25 \mathrm{~mm} \times 30 \mathrm{~m} \times 0.25 \mu \mathrm{m}$ wall-coated fused wax capillary column. The temperature of the oven was programmed with an initial temperature of $160^{\circ} \mathrm{C}$, held for $2 \mathrm{~min}$, and a final temperature of $230^{\circ} \mathrm{C}$, held for $5 \mathrm{~min}$. The temperature was increased at a rate of $5{ }^{\circ} \mathrm{C} / \mathrm{min}$. The injector and the detector temperatures were $230^{\circ} \mathrm{C}$ and $280{ }^{\circ} \mathrm{C}$, respectively. Helium was used as carrier gas, and flow rate was $1 \mathrm{ml} / \mathrm{min}$ when measured at the outlet terminal. Split ratio of injector was approximately 1:50. Eluting peaks were identified by comparison with retention time of known mixed standards (Supelco 37, Bellefonte, PA, USA).

\section{Statistical analyses}

All data obtained were subjective to analysis by the General Linear Models procedures considering genotypic treatment as effect. Comparisons among genotypic treatment means were carried out by the Tukey's test (SAS version 8.2 for Windows; SAS, 2001). The tables give the least square mean values for the genotypic treatments, the corresponding standard errors of the mean (SEM) and the probabilities of error (p-level).

\section{Results and discussion}

\section{Carcass characteristics}

The carcass data of the Thai indigenous (TH), Thai native $\mathrm{x}$ Bar Plymouth Rock (THB), Bar Plymouth Rock (BPR) and Shanghai (SH) male chickens is given in Table 1. For slaughter weights at the same age, there were highly significant differences among genotypes. The slowed growth rate reduced final weight more in the indigenous strain than in the hen and crossbred. It is clear that SH and BPR are improved type breeds and the rest are indigenous and crossbred chicks. Chickens from the indigenous strain were also bigger than black-boned chickens in Thailand that JATURASITHA et al. (2008) who reported a liveweight of 1,100 $\mathrm{g}$ at 16 weeks of age. These results are expected since the goal of genetic selection in modern poultry has been to increase the growth rate and final weight (BRAMFELD et al., 2003). These results have also been found in the study of the indigenous and the crossbred (TH $\mathrm{x}$ Rhode) by JATURASITHA et al. (2002). Expressed as a percentage of chilled carcass weight did not differ significantly from each retail cuts in terms of breast, thigh and M. pectoralis minor percentages except higher drum stick percentage of hen. In contrast, in Thai cutting style found breast without bone percentage of TH was higher than those of hens and crossbred. This data of Thai style cutting confirm that TH is favorable because it has more meat but less bone in carcass composition. These can be explained by the difference in genotypes because SH and BPR are layer so they were not selected for meat type (KASETSUWAN, 1995).

\section{Physiochemical characteristics and water holding capacity (WHC)}

Color, $\mathrm{pH}, \mathrm{EC}$ and water holding capacity is shown in Table 2. The EC values in breast and thigh muscle at $45 \mathrm{~min}$ and $24 \mathrm{~h} \mathrm{p.m.} \mathrm{as} \mathrm{well} \mathrm{as} \mathrm{pH} 45$ min of all genotypes were not significantly different. This may be the result of good transportation and rest period even though indigenous strain has a more aggressive and alert behaviour than the imported breeds (JATURASITHA et al., 2008). This finding was similar to QUENTIN et al. (2003) and KISIEL and KSIAZKIEWICZ (2004) who reported that 
Table 1

Carcass quality of the chickens slaughtered at an age of 16 weeks $n=60$ per genotype

(Schlachtkörperzusammensetzung der Masthähnchen mit einem Alter von 16 Wochen, $\mathrm{n}=60$ je Genotyp)

\begin{tabular}{lcccccc}
\hline Chicken genotypes & \multicolumn{1}{c}{ TH } & THB & BPR & SH & SEM & P \\
\hline Slaughter weight (kg) & $1.28^{\mathrm{b}}$ & $1.48^{\mathrm{ab}}$ & $1.64^{\mathrm{a}}$ & $1.70^{\mathrm{a}}$ & 0.058 & 0.001 \\
Dressing (\%) & 65.8 & 62.4 & 63.8 & 65.8 & 0.09 & 0.089 \\
Retail cuts (\% of chilled carcass weight) & & & & & \\
Breast with bones & 17.7 & 16.4 & 15.7 & 14.8 & 0.07 & 0.136 \\
Thigh with bones & 19.6 & 20.3 & 19.9 & 20.5 & 0.05 & 0.794 \\
Drumstick with bones & $16.7^{\mathrm{ab}}$ & $16.5^{\mathrm{b}}$ & $18.2^{\mathrm{a}}$ & $17.9^{\mathrm{a}}$ & 0.03 & 0.011 \\
Tenderloin (P. minor) & 5.3 & 4.6 & 4.8 & 4.5 & 0.02 & 0.110 \\
Four portion cuts (\%) & 59.3 & 57.8 & 58.6 & 57.6 & 0.09 & 0.724 \\
Thai cutting style without bone $(\%$ of chilled carcass weight) & & & \\
Breast & $14.5^{\mathrm{a}}$ & $12.0^{\mathrm{b}}$ & $12.2^{\mathrm{a}}$ & $10.9^{\mathrm{b}}$ & 0.05 & 0.002 \\
Thigh & 13.0 & 13.0 & 12.9 & 13.3 & 0.04 & 0.929 \\
Drumstick & 10.5 & 9.9 & 11.1 & 10.8 & 0.03 & 0.072 \\
Tenderloin & 5.3 & 4.6 & 4.8 & 4.5 & 0.02 & 0.110 \\
Total lean & 50.4 & 48.2 & 47.3 & 48.7 & 0.09 & 0.292 \\
Bone & $41.4^{\mathrm{b}}$ & $44.3^{\mathrm{ab}}$ & $44.4^{\mathrm{a}}$ & $43.5^{\mathrm{ab}}$ & 0.06 & 0.038 \\
Lean : Bone ratio & $1.23^{\mathrm{a}}$ & $1.09^{\mathrm{ab}}$ & $1.07^{\mathrm{b}}$ & $1.13^{\mathrm{ab}}$ & 0.003 & 0.047 \\
\hline
\end{tabular}

Table 2

Meat quality parameters of the chickens, n=20 (Fleischqualitätsparameter der Masthähnchen, n=20)

\begin{tabular}{|c|c|c|c|c|c|c|}
\hline Chicken genotypes $^{1}$ & $\mathrm{TH}$ & THB & $\mathrm{BPR}$ & $\mathrm{SH}$ & SEM & $\mathrm{P}$ \\
\hline \multicolumn{7}{|c|}{ Breast meat $p H$ and electrical conductivity } \\
\hline $\mathrm{pH}_{45 \min }$ & 5.89 & 6.06 & 5.99 & 6.02 & 0.006 & 0.385 \\
\hline $\mathrm{pH}_{24 \mathrm{~h}}$ & $5.77^{\mathrm{b}}$ & $6.02^{\mathrm{a}}$ & $6.11^{\mathrm{a}}$ & $5.71^{\mathrm{b}}$ & 0.004 & 0.001 \\
\hline $\mathrm{EC}_{45 \min }(\mathrm{mS} / \mathrm{cm})$ & 4.00 & 4.76 & 4.75 & 2.46 & 0.068 & 0.211 \\
\hline $\mathrm{EC}_{24 \mathrm{~h}}(\mathrm{mS} / \mathrm{cm})$ & 5.33 & 4.82 & 5.70 & 5.35 & 0.022 & 0.191 \\
\hline \multicolumn{7}{|l|}{ Meat color } \\
\hline \multicolumn{7}{|l|}{ Breast } \\
\hline $\mathrm{L}^{*}$ & $54.8^{b}$ & $53.5^{\mathrm{b}}$ & $55.8^{\mathrm{b}}$ & $59.1^{\mathrm{a}}$ & 0.09 & 0.001 \\
\hline$a^{*}$ & $1.27^{\mathrm{ab}}$ & $2.23^{\mathrm{a}}$ & $1.86^{\mathrm{ab}}$ & $-0.08^{\mathrm{b}}$ & 0.041 & 0.018 \\
\hline$b^{*}$ & $13.6^{\mathrm{a}}$ & $8.5 \mathrm{c}$ & $9.9^{\mathrm{bc}}$ & $11.9^{\mathrm{ab}}$ & 0.05 & 0.001 \\
\hline \multicolumn{7}{|l|}{ Thigh color } \\
\hline $\mathrm{L}^{*}$ & $51.9^{\mathrm{b}}$ & $54.1^{\mathrm{b}}$ & $54.3^{b}$ & $57.9^{\mathrm{a}}$ & 0.07 & 0.001 \\
\hline$a^{*}$ & $5.27^{\mathrm{a}}$ & $2.53^{\mathrm{b}}$ & $3.47^{\mathrm{ab}}$ & $3.92^{\mathrm{ab}}$ & 0.038 & 0.003 \\
\hline$b^{*}$ & $7.82^{\mathrm{a}}$ & $4.87^{\mathrm{b}}$ & $5.13^{\mathrm{b}}$ & $6.32^{\mathrm{ab}}$ & 0.055 & 0.018 \\
\hline \multicolumn{7}{|c|}{ Water holding capacity (loss, \% of total) } \\
\hline \multicolumn{7}{|l|}{ Breast meat } \\
\hline Drip & 6.39 & 5.97 & 5.52 & 6.45 & 0.197 & 0.044 \\
\hline Thawing & $3.64^{\mathrm{b}}$ & $5.80^{\mathrm{a}}$ & $4.66^{\mathrm{ab}}$ & $4.56^{\mathrm{ab}}$ & 0.056 & 0.038 \\
\hline Boiling & $18.99^{\mathrm{b}}$ & $23.75^{\mathrm{a}}$ & $24.93^{\mathrm{a}}$ & $21.07^{\mathrm{ab}}$ & 0.123 & 0.005 \\
\hline Grilling & 20.66 & 22.36 & 21.05 & 23.30 & 0.106 & 0.163 \\
\hline \multicolumn{7}{|l|}{ Thigh meat } \\
\hline Drip & 3.42 & 2.53 & 5.06 & 3.97 & 0.103 & 0.227 \\
\hline Thawing & 2.73 & 4.30 & 3.39 & 3.87 & 0.053 & 0.111 \\
\hline Boiling & 23.38 & 21.60 & 20.04 & 25.78 & 0.197 & 0.113 \\
\hline Grilling & $27.65^{\mathrm{a}}$ & $23.47^{\mathrm{ab}}$ & $18.45^{\mathrm{b}}$ & $28.68^{\mathrm{a}}$ & 0.232 & 0.008 \\
\hline
\end{tabular}

a-b Means within row carrying no common superscripts are significantly different at $\mathrm{P}<0.05$

1: $\mathrm{TH}=$ Thai indigenous chicken; $\mathrm{THB}=$ Thai indigenous chicken $\times$ Bar Plymouth Rock; $\mathrm{BPR}=\mathrm{Bar}$ Plymouth Rock; $\mathrm{SH}=\mathrm{Shanghai}$

Breast and thigh meat color in terms of $\mathrm{L}^{*}, \mathrm{a}^{*}$ and $\mathrm{b}^{*}$ values displayed significant differences among genotypes $(\mathrm{P}<0.001)$. Breast color of SH had higher $\mathrm{L}^{*}$ and $\mathrm{b}^{*}$ but lower $\mathrm{a}^{*}$ values. This means that $\mathrm{SH}$ had paler and yellower breast whereas $\mathrm{TH}$ had a 
redder and yellower thigh meat. The findings were similar to those in JATURASITHA et al. (2004a and 2008) that studied Thai, broiler, other indigenous strains and hen. Whereas, YANG and JIANG (2005) reported that breast and thigh of fast growing chickens was higher than those of slow-growing chickens.

The water holding capacity in terms of drip, thaw and cooking (boiling and grilling methods) losses of breast and thigh muscle was significantly different among genotypes. TH had higher drip loss percentage but lower thawing and boiling losses in breast muscle than the crossbred (THB), whereas these losses of breast muscle of hens were in between. The grilling loss of thigh muscle of BPR was the lowest among genotypes. Whereas JOSEPH et al. (1997) reported that fat loss from high temperature $\left(85^{\circ} \mathrm{C}\right)$ caused increasing fluid loss in meat, the internal temperatures of the current study's samples were only $80^{\circ} \mathrm{C}$. This may be the different among genotypes which can be hold the water molecule in meat (BEE et al., 2007)

\section{Histological properties}

The muscle fibers are commonly classified into three groups: slow-twitch oxidative (STO), fast twitch oxidative-glycolytic (FTO), and fast twitch glycolytic (FTG) according to their biochemical and functional properties (BROOK and KAISER, 1970) (Table 3). Dark muscles contain predominantly STO, while light muscles contain primarily FTG. There was no significant difference in the percentage of number of breast muscle fiber types among genotypes. LENGERKEN VON et al. (2002) reported that pectoralis of broiler and turkey contained FTG 99.5 and $99.8 \%$; respectively whereas in this investigation found type IIB between 82.2-95.0 \%

Table 3

Muscle fiber ${ }^{1}$ parameters of the breast (pectoralis major) and thigh muscle (M. biceps femoris) in the chickens, $\mathrm{n}=10$ (Muskelfaserparameter im großen Brustmuskel [pectoralis major] und im Oberschenkel [M. biceps femoris] der Masthähnchen, $\mathrm{n}=10$ )

\begin{tabular}{|c|c|c|c|c|c|c|}
\hline Chicken genotypes $^{2}$ & $\mathrm{TH}$ & THB & BPR & $\mathrm{SH}$ & SEM & $\mathrm{P}$ \\
\hline \multicolumn{7}{|l|}{ Breast muscle } \\
\hline \multicolumn{7}{|c|}{ Fiber count $(\%$ of total $)$} \\
\hline Type I & 1.1 & 0.6 & 0.9 & 4.6 & 0.61 & 0.088 \\
\hline Type IIA & 3.9 & 8.2 & 5.1 & 13.2 & 1.40 & 0.160 \\
\hline Type IIB & 95.0 & 91.2 & 94.0 & 82.2 & 1.75 & 0.054 \\
\hline \multicolumn{7}{|c|}{ Cross sectional area (diameter, $\mu \mathrm{m})$} \\
\hline Type I & $10.4^{\mathrm{c}}$ & $26.4^{\mathrm{b}}$ & $22.4^{\mathrm{b}}$ & $35.4^{\mathrm{a}}$ & 1.092 & 0.001 \\
\hline Type IIA & $19.0^{\mathrm{d}}$ & $38.7^{\mathrm{b}}$ & $27.7^{\mathrm{c}}$ & $42.7^{\mathrm{a}}$ & 0.620 & 0.001 \\
\hline Type IIB & $45.7^{\mathrm{c}}$ & $48.1^{\mathrm{b}}$ & $45.9^{\mathrm{c}}$ & $50.4^{\mathrm{a}}$ & 0.182 & 0.001 \\
\hline \multicolumn{7}{|l|}{ Thigh muscle } \\
\hline \multicolumn{7}{|c|}{ Fiber count ( $\%$ of total $)$} \\
\hline Type I & $18.2^{\mathrm{a}}$ & $8.5^{\mathrm{b}}$ & $10.8^{b}$ & $8.5^{\mathrm{b}}$ & 0.47 & 0.001 \\
\hline Type IIA & 26.0 & 23.6 & 24.7 & 26.1 & 0.91 & 0.722 \\
\hline Type IIB & $55.8^{\mathrm{y}}$ & $67.9^{\mathrm{x}}$ & $64.5^{\mathrm{x}}$ & $65.4^{\mathrm{x}}$ & 1.06 & 0.002 \\
\hline \multicolumn{7}{|c|}{ Cross sectional area (diameter, $\mu \mathrm{m})$} \\
\hline Type I & $23.8^{\mathrm{a}}$ & $17.7^{\mathrm{b}}$ & $24.8^{\mathrm{a}}$ & $17.6^{\mathrm{b}}$ & 0.302 & 0.001 \\
\hline Type IIA & $41.2^{\mathrm{n}}$ & $42.1^{\mathrm{mn}}$ & $40.7^{\mathrm{n}}$ & $42.6^{\mathrm{m}}$ & 0.244 & 0.020 \\
\hline Type IIB & $55.5^{\mathrm{b}}$ & $59.6^{\mathrm{a}}$ & $56.5^{\mathrm{b}}$ & $59.1^{\mathrm{a}}$ & 0.229 & 0.001 \\
\hline
\end{tabular}


The cross-sectional area (diameter) of breast muscle types was significantly different among genotypes. The STO, FTO and FTG diameters of TH breast were smaller than those of hens and crossbred. These results were contrasted by WATTANACHANT et al. (2005) that found the fiber diameter of breast and thigh of Thai indigenous chicken was bigger than those of broiler. The result of thigh muscle in terms of the percentages of muscle fiber types found that TH had more STO but less FTG percentages than those of hens and crossbred. In addition, the cross section area of muscle fiber types of TH had bigger STO but small FTG compared to all genotypes. In the modern breeds, this probably reflects breeding for higher muscle accretion which is often associated with a shift from oxidative to glycolytic muscle metabolism (KLOSOWSKA et al., 2005)

Table 4

Chemical composition, texture and sensory grading of meat from the chickens, $n=20$

(Chemische Zusammensetzung, Textur und Sensorik im Masthuhnfleisch, $\mathrm{n}=20$ )

\begin{tabular}{|c|c|c|c|c|c|c|}
\hline Chicken genotypes $^{1}$ & $\mathrm{TH}$ & THB & $\mathrm{BPR}$ & $\mathrm{SH}$ & SEM & $\mathrm{P}$ \\
\hline \multicolumn{7}{|l|}{ Breast muscle } \\
\hline \multicolumn{7}{|c|}{ Chemical composition $(\mathrm{g} / 100 \mathrm{~g})$} \\
\hline Moisture & 72.9 & 73.4 & 73.3 & 73.3 & 0.05 & 0.943 \\
\hline Protein & 24.7 & 23.1 & 24.2 & 23.9 & 0.04 & 0.155 \\
\hline Fat & 0.51 & 0.43 & 0.56 & 0.59 & 0.006 & 0.329 \\
\hline Triglyceride (g/100 g) & 0.37 & 0.38 & 0.47 & 0.50 & 0.004 & 0.354 \\
\hline Cholesterol (mg/100 g) & 12.4 & 10.9 & 15.1 & 15.0 & 0.07 & 0.029 \\
\hline \multicolumn{7}{|l|}{ Collagen $(\mathrm{mg} / \mathrm{g})$} \\
\hline Soluble & 11.4 & 10.6 & 13.7 & 12.5 & 0.10 & 0.219 \\
\hline Insoluble & 14.8 & 14.5 & 14.8 & 17.1 & 0.11 & 0.438 \\
\hline \multicolumn{7}{|l|}{ Sensory evaluation $^{2}$} \\
\hline Tenderness & 5.75 & 5.92 & 5.25 & 5.83 & 0.033 & 0.740 \\
\hline Juiciness & 5.17 & 5.42 & 4.92 & 5.25 & 0.029 & 0.853 \\
\hline Flavour & 6.17 & 6.67 & 6.33 & 6.50 & 0.029 & 0.841 \\
\hline Acceptability & 6.00 & 6.50 & 6.00 & 5.75 & 0.029 & 0.601 \\
\hline \multicolumn{7}{|l|}{ Shear force value } \\
\hline Force $(\mathrm{N})$ & $51.2^{\mathrm{a}}$ & $19.9^{\mathrm{b}}$ & $30.9^{\mathrm{b}}$ & $21.9^{\mathrm{b}}$ & 0.28 & 0.001 \\
\hline Energy $(\mathrm{mJ})$ & $225^{\mathrm{a}}$ & $66^{\mathrm{b}}$ & $125^{\mathrm{b}}$ & $77^{\mathrm{b}}$ & 1.3 & 0.001 \\
\hline Extension (mm) & $19.5^{\mathrm{a}}$ & $16.6^{\mathrm{b}}$ & $17.6^{\mathrm{b}}$ & $17.0^{\mathrm{b}}$ & 0.03 & 0.001 \\
\hline \multicolumn{7}{|l|}{ Thigh muscle } \\
\hline \multicolumn{7}{|c|}{ Chemical composition $(\mathrm{g} / 100 \mathrm{~g})$} \\
\hline Moisture & $75.7^{\mathrm{a}}$ & $72.6^{\mathrm{b}}$ & $73.2^{\mathrm{b}}$ & $74.5^{\mathrm{ab}}$ & 0.04 & 0.001 \\
\hline Protein & 20.4 & 20.0 & 21.3 & 19.8 & 0.05 & 0.311 \\
\hline Fat & $2.94^{\mathrm{b}}$ & $4.47^{\mathrm{ab}}$ & $3.83^{\mathrm{b}} \mathrm{c}$ & $5.55^{\mathrm{a}}$ & 0.026 & 0.001 \\
\hline Triglyceride (g/100 g) & $1.50^{\mathrm{c}}$ & $3.45^{\mathrm{b}}$ & $2.70^{\mathrm{bc}}$ & $5.36^{\mathrm{a}}$ & 0.021 & 0.000 \\
\hline Cholesterol (mg/100g) & $58.7^{\mathrm{b}}$ & $68.4^{\mathrm{ab}}$ & $76.5^{\mathrm{ab}}$ & $86.4^{\mathrm{a}}$ & 0.38 & 0.015 \\
\hline \multicolumn{7}{|l|}{ Collagen $(\mathrm{mg} / \mathrm{g})$} \\
\hline Soluble & $16.7^{\mathrm{a}}$ & $10.8^{\mathrm{b}}$ & $12.7^{\mathrm{ab}}$ & $12.5^{\mathrm{ab}}$ & 0.12 & 0.024 \\
\hline Insoluble & 25.5 & 20.3 & 22.1 & 22.2 & 0.17 & 0.298 \\
\hline \multicolumn{7}{|l|}{ Sensory evaluation $^{2}$} \\
\hline Tenderness & 5.50 & 5.92 & 5.75 & 5.83 & 0.023 & 0.806 \\
\hline Juiciness & 5.67 & 5.75 & 6.08 & 5.67 & 0.020 & 0.692 \\
\hline Flavour & 6.92 & 7.17 & 6.75 & 7.08 & 0.024 & 0.817 \\
\hline Acceptability & 6.67 & 6.92 & 6.92 & 7.17 & 0.023 & 0.738 \\
\hline \multicolumn{7}{|l|}{ Shear force value } \\
\hline Force $(\mathrm{N})$ & $44.3^{\mathrm{a}}$ & $31.1^{\mathrm{b}}$ & $35.8^{\mathrm{ab}}$ & $39.2^{\mathrm{ab}}$ & 0.22 & 0.028 \\
\hline Energy $(\mathrm{mJ})$ & $171^{\mathrm{a}}$ & $102^{\mathrm{b}}$ & $112^{\mathrm{b}}$ & $151^{\mathrm{ab}}$ & 1.1 & 0.005 \\
\hline Extension (mm) & $17.5^{\mathrm{b}}$ & $19.0^{\mathrm{a}}$ & $18.8^{\mathrm{ab}}$ & $19.3^{\mathrm{a}}$ & 0.027 & 0.009 \\
\hline
\end{tabular}

a-c Means within row carrying no common superscripts are significantly different at $\mathrm{P}<0.05$

1: $\mathrm{TH}=$ Thai indigenous chicken; $\mathrm{THB}=$ Thai indigenous chicken $\times$ Bar Plymouth Rock; $\mathrm{BPR}=\mathrm{Bar}$ Plymouth Rock; $\mathrm{SH}=\mathrm{Shanghai}$

2: $1=$ extremely tough, dry, bland or undesired; $9=$ extremely tender, juicy, intense or desired 
and, at very high selection intensity (which is probably not yet the case for BPR and $\mathrm{SH}$ ), a higher frequency of meat quality problems.

\section{Chemical composition, texture and sensory grading}

The result of chemical composition, texture and sensory evaluation of breast and thigh muscle is provided in Table 4. Protein, fat and moisture percentage of breast muscle was not significantly different among genotypes. This was similar to the finding of NOWSAD et al. (2000). However, it was slightly different from the finding in SHAARANI et al. (2006) where the moisture percentage of broiler was $76 \%$. The fat content (intramuscular fat) of thigh muscle from all hen and crossbred was higher than TH $(\mathrm{P}<0.05)$ but it was still lower than the finding of LEE et al. (2003) in spent hen. In addition, cholesterol and triglyceride content were significantly lower in Thai indigenous strain (TH) compared to hen and crossbred breeds (SH, BPR and THB).

These results were supported by the findings in JATURASITHA et al. (2002) concerning different breeds of Thai chickens and poultry. It can be attributed to the different of strains. BPR and SH chickens are laying type which were selected to have faster growth rate and they should accumulate fat as well (LAWRIE, 1998) and triglyceride content has positive correlation with fat content (BIEDERMANN et al., 2000). Collagen content of breast muscle was not significantly different among groups but $\mathrm{TH}$ tended to have higher insoluble collagen content in thigh muscle than hen and crossbred. Therefore, this result affected the high shear values (KLANDORF et al., 1996). This result was supported by the finding in DING et al. (1999) which compared Chinese local chickens to broiler. In the present study, the chickens were at the same slaughter age; therefore, they should have not much different collagen content. Breast and thigh muscle of crossbred hen (THB) had less shear force than TH chicken by almost $1-2$ folds $(\mathrm{P}<0.05)$ but there were no significant difference in the sensory evaluation in terms of tenderness, juiciness, flavour and overall acceptability. However, LEE et al. (2003) found that meat from hen ( 72 weeks) was tougher than that of broiler and NUTE (1999) reported texture and juiciness of improved chicken genotype was better than those of indigenous strains. JATURASITHA et al. (2008) reported Thai people preferred chewy chicken meat to poultry meat.

\section{Fatty acid composition}

The fatty acid composition results analyzed from breast and thigh muscles are presented in Table 5. Chicken meat contained more unsaturated fatty acids which are monounsaturated fatty acid (MUFA) and polyunsaturated fatty acid (PUFA) than pork (AUMAITRE, 1999). TH chicken breast muscle had not much different fatty acid profile from hen and crossbred. In contrast, thigh muscle of TH had higher total SFA and total n-3 fatty acid but lower total MUFA than other genotypes $(\mathrm{P}<0.05)$. This is similar to previous studies (JATURASITHA et al., 2004b and 2008). THI chicken thigh meat had higher concentrations of n-3 fatty acids group i.e. C18:3 and C22:6 than other groups $(\mathrm{P}<0.05)$. Therefore, the ratio of $n-6: n-3$ fatty acid in TH chicken thigh meat is more favorable than those of the other chickens. This would be a strong point of TH chicken meat.

The present study showed several and different characteristic features for Thai indigenous strain and hen and their crossbred. Apart from lean : bone ratio this included IMF, cholesterol and triglyceride contents of Thai indigenous strain were higher than those all genotypes. It also had the favorable fatty acids in terms of high n-3 and n-6:n-3 ratio fatty acids. The sensory evaluation of both muscles was not significant difference 
among genotypes. Therefore, it would be alternative to Thai indigenous chicken with the male layer and male crossbred for Thai consumers who are preferable as chewy meat to the tender broiler meat while $\mathrm{TH}$ is still insufficient production according to low growth rate.

Table 5

Fatty acid ${ }^{1}$ composition of the meat of the chickens, $n=20$ (Fettsäurezusammensetzung im Masthuhnfleisch, n=20)

\begin{tabular}{|c|c|c|c|c|c|c|}
\hline \multirow[t]{2}{*}{ Chicken genotypes $^{2}$} & $\mathrm{TH}$ & THB & BRP & $\mathrm{SH}$ & \multirow[t]{2}{*}{ SEM } & \multirow[t]{2}{*}{$\mathrm{P}$} \\
\hline & & of totally & ysed fatt & s- & & \\
\hline \multicolumn{7}{|l|}{ Breast muscle } \\
\hline C12:0 & $0.57^{\mathrm{a}}$ & $0.38^{\mathrm{b}}$ & $0.52^{\mathrm{ab}}$ & $0.59^{\mathrm{a}}$ & 0.003 & 0.020 \\
\hline C14:0 & 0.72 & 0.85 & 0.87 & 0.78 & 0.003 & 0.179 \\
\hline C16:0 & 27.00 & 25.61 & 26.75 & 26.96 & 0.033 & 0.216 \\
\hline C16:1 & 3.46 & 2.61 & 3.75 & 2.95 & 0.019 & 0.053 \\
\hline C18:0 & $8.05^{\mathrm{b}}$ & $9.37^{\mathrm{a}}$ & $8.10^{\mathrm{b}}$ & $9.48^{\mathrm{a}}$ & 0.013 & 0.001 \\
\hline $\mathrm{C} 21: 0$ & $0.35^{\mathrm{a}}$ & $0.21^{\mathrm{ab}}$ & $0.09^{\mathrm{b}}$ & $0.32^{\mathrm{a}}$ & 0.004 & 0.010 \\
\hline $\mathrm{C} 23: 0$ & $0.54^{\mathrm{a}}$ & $0.40^{\mathrm{ab}}$ & $0.15^{\mathrm{b}}$ & $0.52^{\mathrm{a}}$ & 0.005 & 0.003 \\
\hline $\mathrm{C} 24: 0$ & 0.99 & 0.40 & 0.46 & 0.75 & 0.010 & 0.044 \\
\hline C18:1 n-9 & 1.63 & 1.62 & 1.68 & 1.74 & 0.002 & 0.139 \\
\hline C18:1 trans & $23.82^{\mathrm{b}}$ & $24.78^{\mathrm{ab}}$ & $26.85^{\mathrm{a}}$ & $22.61^{\mathrm{b}}$ & 0.037 & 0.001 \\
\hline C20_1 & $0.18^{\mathrm{b}}$ & $0.38^{\mathrm{a}}$ & $0.36^{\mathrm{a}}$ & $0.15^{\mathrm{b}}$ & 0.002 & 0.001 \\
\hline C18:2 n-6 & $26.38^{\mathrm{bc}}$ & $28.36^{\mathrm{a}}$ & $27.36^{\mathrm{ab}}$ & $25.29^{\mathrm{b}}$ & 0.030 & 0.001 \\
\hline C20_2 & $0.03^{\mathrm{b}}$ & $0.22^{\mathrm{a}}$ & $0.07^{\mathrm{b}}$ & $0.14^{\mathrm{ab}}$ & 0.000 & 0.001 \\
\hline C18:3 n-3 & 0.52 & 0.62 & 0.65 & 0.54 & 0.003 & 0.084 \\
\hline C20:4 n-6 & $3.72^{\mathrm{a}}$ & $3.07^{\mathrm{ab}}$ & $1.66^{\mathrm{b}}$ & $5.04^{\mathrm{a}}$ & 0.033 & 0.001 \\
\hline$C 22: 6 n-3$ & $2.03^{\mathrm{ab}}$ & $1.13^{b c}$ & $0.67^{\mathrm{c}}$ & $2.17^{\mathrm{a}}$ & 0.016 & 0.001 \\
\hline Total SFA & $38.23^{\mathrm{ab}}$ & $37.22^{\mathrm{b}}$ & $36.94^{\mathrm{b}}$ & $39.39^{\mathrm{a}}$ & 0.031 & 0.004 \\
\hline Total MUFA & $29.08^{\mathrm{b}}$ & $29.39^{\mathrm{b}}$ & $32.65^{\mathrm{a}}$ & $27.44^{\mathrm{b}}$ & 0.052 & 0.001 \\
\hline Total PUFA & $32.69^{\mathrm{ab}}$ & $33.40^{\mathrm{a}}$ & $30.42^{\mathrm{b}}$ & $33.17^{\mathrm{b}}$ & 0.049 & 0.035 \\
\hline Total n-6 FA & $30.10^{\mathrm{ab}}$ & $31.43^{\mathrm{a}}$ & $29.02^{\mathrm{b}}$ & $30.32^{\mathrm{ab}}$ & 0.038 & 0.059 \\
\hline Total n-3 FA & $2.55^{\mathrm{ab}}$ & $1.74^{\mathrm{bc}}$ & $1.32^{\mathrm{c}}$ & $2.71^{\mathrm{a}}$ & 0.015 & 0.001 \\
\hline$n-6 / n-3$ & $15.24^{\mathrm{b}}$ & $18.06^{\mathrm{ab}}$ & $22.80^{\mathrm{a}}$ & $14.29^{\mathrm{b}}$ & 0.098 & 0.001 \\
\hline \multicolumn{7}{|l|}{ Thigh muscle } \\
\hline C12:0 & $0.63^{\mathrm{a}}$ & $0.28^{\mathrm{b}}$ & $0.19^{\mathrm{b}}$ & $0.39^{\mathrm{b}}$ & 0.004 & 0.001 \\
\hline C14:0 & 0.75 & 0.73 & 0.77 & 0.86 & 0.002 & 0.089 \\
\hline C16:0 & $27.46^{\mathrm{a}}$ & $25.69^{\mathrm{b}}$ & $26.24^{\mathrm{ab}}$ & $26.87^{\mathrm{ab}}$ & 0.026 & 0.025 \\
\hline C16:1 & 2.59 & 2.68 & 2.88 & 3.82 & 0.021 & 0.049 \\
\hline C18:0 & 9.82 & 9.07 & 8.46 & 11.00 & 0.053 & 0.185 \\
\hline $\mathrm{C} 21: 0$ & $0.35^{\mathrm{a}}$ & $0.20^{\mathrm{ab}}$ & $0.09^{\mathrm{b}}$ & $0.04^{b}$ & 0.003 & 0.001 \\
\hline $\mathrm{C} 23: 0$ & 0.57 & 0.61 & 0.55 & 0.41 & 0.005 & 0.291 \\
\hline $\mathrm{C} 24: 0$ & $0.90^{\mathrm{a}}$ & $0.60^{\mathrm{ab}}$ & $0.44^{\mathrm{b}}$ & $0.39^{\mathrm{b}}$ & 0.007 & 0.010 \\
\hline C18:1 n-9 & $1.67^{\mathrm{a}}$ & $1.70^{\mathrm{a}}$ & $1.60^{\mathrm{ab}}$ & $1.48^{\mathrm{b}}$ & 0.003 & 0.002 \\
\hline C18:1 trans & $21.17^{\mathrm{c}}$ & $23.97^{\mathrm{ab}}$ & $24.83^{\mathrm{a}}$ & $22.18^{\mathrm{bc}}$ & 0.033 & 0.001 \\
\hline $\mathrm{C} 20 \_1$ & $0.08^{c}$ & $0.34^{\mathrm{ab}}$ & $0.39^{\mathrm{a}}$ & $0.23^{\mathrm{b}}$ & 0.002 & 0.001 \\
\hline C18:2 n-6 & $24.45^{\mathrm{b}}$ & $26.99^{\mathrm{ab}}$ & $28.10^{\mathrm{a}}$ & $27.31^{\mathrm{a}}$ & 0.047 & 0.007 \\
\hline $\mathrm{C} 20 \_2$ & 0.05 & 0.12 & 0.07 & 0.05 & 0.001 & 0.277 \\
\hline C18:3 n-3 & $0.68^{\mathrm{ab}}$ & $0.55^{\mathrm{b}}$ & $0.57^{\mathrm{b}}$ & $0.88^{\mathrm{a}}$ & 0.004 & 0.002 \\
\hline C20:4 n-6 & $5.92^{\mathrm{a}}$ & $4.43^{\mathrm{ab}}$ & $3.39^{\mathrm{b}}$ & $2.74^{\mathrm{b}}$ & 0.038 & 0.003 \\
\hline$C 22: 6 n-3$ & $2.91^{\mathrm{a}}$ & $2.04^{\mathrm{ab}}$ & $1.42^{\mathrm{b}}$ & $1.36^{\mathrm{b}}$ & 0.015 & 0.001 \\
\hline Total SFA & $40.48^{\mathrm{a}}$ & $37.18^{\mathrm{b}}$ & $36.72^{\mathrm{b}}$ & $39.96^{\mathrm{a}}$ & 0.044 & 0.001 \\
\hline Total MUFA & $25.52^{\mathrm{b}}$ & $28.69^{\mathrm{a}}$ & $29.70^{\mathrm{a}}$ & $27.71^{\mathrm{ab}}$ & 0.044 & 0.001 \\
\hline Total PUFA & 34.01 & 34.14 & 33.57 & 32.33 & 0.046 & 0.298 \\
\hline Total n-6 FA & 30.37 & 31.42 & 31.50 & 30.04 & 0.040 & 0.276 \\
\hline Total n-3 & $3.59^{\mathrm{a}}$ & $2.59^{\mathrm{b}}$ & $2.00^{\mathrm{b}}$ & $2.24^{\mathrm{b}}$ & 0.015 & 0.001 \\
\hline$n-6 / n-3$ & $9.77^{\mathrm{b}}$ & $14.33^{\mathrm{ab}}$ & $18.25^{\mathrm{a}}$ & $14.02^{\mathrm{ab}}$ & 0.083 & 0.001 \\
\hline
\end{tabular}

a-c Means within row carrying no common superscripts are significantly different at $\mathrm{P}<0.05$

1: SFA, saturated fatty acids, MUFA, monounsaturated fatty acids, PUFA, polyunsaturated fatty acids

2: $\mathrm{TH}=$ Thai indigenous chicken; $\mathrm{THB}=$ Thai indigenous chicken $\times$ Bar Plymouth Rock; $\mathrm{BPR}=\mathrm{Bar}$ Plymouth Rock; $\mathrm{SH}=\mathrm{Shanghai}$ 


\section{Acknowledgements}

The authors would like to appreciate Alexander von Humboldt Stiftung/Foundation for research support.

\section{References}

ABELL, L.L.; BRODIE, B.B.; KENDALL, F.E.:

A simplified method for the estimation of total serum cholesterol in serum and demonstration of its specificity. J. Biol. Chem. 195 (1951), 357-366

AMERINE, M.A.; PANGBORN, R.M.; ROESSLER, E.B.: Principles of Sensory Evaluation of Food. Academic Press. New York, USA (1965)

ANDRASSY-BAKA, G.; ROMVARI, R.; MIRISITS, G.; SÜTÖ, Z.; SZABO, A.; LOCSMANDI, L.; HORN, P. Non-invasive body composition measurement of broiler chicken between 4-18 weeks of age by computer tomography. Arch. Tierz. 46 (2003), 585-595

AOAC:

Official Method of Analysis. Association of Official Analytical Chemists, Arlington, VA. USA (1995)

AUMAITRE, A.:

Quality and safety animal products. Lives. Prod. Sci. 59 (1999), 113-124

BEE, G.; PURSEL, V.G.; MITCHEL, A.D.; MARUYAMA, K.; WELLS, K.D.; SOLOMON, M.B.; WALL, R.J.; COLEMAN, M.E.; SCHWARTZ, R.J.:

Carcass composition and skeletal muscle morphology of swine expressing an insulin-like growth factor I transgene. Arch. Tierz. 50 (2007), 501-519

BERGMAN, M.; LOXLEY, R.:

Two improved and simplified methods for the spectrophotometric determination of hydroxyproline. Anal. Chem. 35 (1963), 1961-1965

BIEDERMANN, G.; JATSCH, C.; PESCHKE, W.; LINDER, J.-P.; WITTMAN, W.:

Mast und Schlachleistung sowie Fleisch- und Fettqualität von Pietrainschweinen unterschiedlichen MHS-Genotyps und Geschlechts. 2. Mitt.: Fettsäuremuster der Depotfette Rückenspeck, Flomen und intramukuläres Fett sowie der Gesamt- und Phospholipide des M. Long dorsi. Arch. Tierz. 43 (2000), $165-178$

BIGGS, H.G.; ERIKSON, J.M., MOOREHEAD, W.R.:

A manual colorimetric assay of triglycerides in serum. Clin. Chem. 21 (1975), 437-441

BRAMFELD, J.M.; FAHEY, A.J.; LANGLEY-EVANS, S.C.; BUTTERY, P.J.:

Nutritional and hormonal control of muscle growth and fat deposition. Arch. Tierz. 46 (2003) Special Issue, 143-156

BROOKE, M.H.; KAISER, K.K.:

Muscle fibre types: how many and what kind? Arch. Neuro. 23 (1970), 369-379

DING, H.; XU, R.J.; CHAN, D.K.O.:

Identification of broiler chicken meat using a visible/near-infrared spectroscopic technique. J. Sci. Food Agric. 79 (1999), 1382-1388

FEDERATION OF ANIMAL SCIENCE SOCIETIES.:

Guidelines for the Care and Use of Agricultural Animals in Agricultural Research and Teaching. $1^{\text {st }}$ rev. ed. Fed. Anim. Sci. Soc., Savoy, IL. (1999)

FERNANDEZ, X.; MONIN, G.; TALMANT, A.; MOUROT, J.; LEBRET, B.:

Influence of intramuscularfat content on the quality of pig meat: 1 . Composition of lipid fraction and sensory characteristics of m. Longissimus lumborum. Meat Sci. 53 (1999), 59-65

FOLCH, J.; LEES, M.; STANLEY, G.H.S.:

A simple method for the isolation and purification of total lipids from animal tissue. J. Biol. Chem. 226 (1957), 497-509

HENRICKSON, R.L.:

HILL, F.: Meat, Poultry and Seafood Technology. Prentice-Hall Inc., Englewood Cliffs, New Jersey, USA (1978)

HONIKEL, K.O.:

How to measure the water-holding capacity of meat? Recommendation of the standardized method. Pages 129-142 in Evaluation and Control of Meat Quality in Pigs? P. V. TARRANT, G. HORAK, V.: EIKELENBOOM and G. MONIN ed. MARTINUS NIJHOFF, Publishers, The Hague. (1987)

A successive histochemical staining for succinate dehydrogenase and "reversed" - ATPase in a single section for the skeletal muscle fibre typing. Histochem. 78 (1983), 545-553 
JACOB, J.; MATHER, F.B.:

Capon. Institute of Food and Agricultural Sciences, University of Florida [Online]. Available: http://edis.ufl.edu. [2005, September 12] (2000)

JATURASITHA, S.: Meat Technology. Thanabun Press. Chiang Mai. Thailand. (2000)

JATURASITHA, S.: Meat Management. Mingmuang Press. Chiang Mai, Thailand. (2004)

JATURASITHA, S.; KHIAOSAARD, R.; PONGPAEW, A.; LEOWTHARAKUL, A; SAITONG, S.; APICHATSARANGKUL, T.; LEAUNGWUNTA, V.: Carcass and indirect meat quality of native and Kai Baan Thai chickens with different sex and slaughter weight, in: Proceedings of the $42^{\text {nd }}$ Annual Conference. Kasetsart University, Bangkok, Thailand. (2004a), 116-126 [in Thai]

JATURASITHA, S.; KHIAOSAARD, R.; PONGPAEW, A.; LEOWTHARAKUL, A; SAITONG, S.; APICHATSARANGKUL, T.; LEAUNGWUNTA, V.; LANGANI, N.:

The effects of strain, sex, weight, and muscle on fat quality of Thai native and crossbred chickens (Kai Baan Thai), in: Proceedings of the $42^{\text {nd }}$ Annual Conference. Kasetsart University, Bangkok, Thailand. (2004b), 137-146 [in Thai]

JATURASITHA, S.; SRIKANCHAI, T.; KREUZER, M.; WICKE, M.:

Differences in carcass and meat characteristics between chicken indigenous to Northern Thailand (Black-boned and Thai Native) and imported extensive breeds (Bresse and Rhode Island Red). Poult. Sci. 87 (2008), 160-169

JATURASITHA, S.; LEANGWUNTA, V.; LEOTARAGUL, A.; PHONGPHAEW, A.; APICHARTSRUNGKOON, T.; SIMASATHITKUL, N.; VEARASILP, T.; WORACHAI, L.; TER MEULEN, U.:

A comparative study of Thai native chicken and broiler on productive performance, carcass and meat quality. Deutscher Tropentag.Witzenhausen, Germany, (Abstr.) (2002)

JOSEPH, J.K.; AWOSANYA, B.; ADENIRAN, A.T.; OTAGBA, U.M.:

The effect of end-point internal cooking temperatures on the meat quality attributes of selected Nigerian poultry meats. Food Qual. Prefre. 8 (1997), 57-61

JUNG, D.H.; BIGGS, H.G., MOOREHEAD, W.R.:

Colorimetry of serum cholesterol with use of ferric acetate uranyl acetate and ferrous sulfate/sulfuric acid reagents. Clin. Chem. 21 (1975), 1526-1530

KASETSUWAN, S.: Chicken Production. Kasetsat Press, Bangkok. Thailand. (1995)

KISIEL, T.; KSIAZKIEWICZ, J.M.:

Comparison of physical and qualitative traits of meat of two Polish conservative flocks of duck. Arch. Tierz. 47 (2004), 367-375

KLANDORF, H.; ZHOU, Q.; SAMS, A.R.:

Inhibition by aminoguanidine of glucose-derived collagen cross-link in skeletal muscle of broiler breeder hens. Poult. Sci. 75 (1996), 432-437

KLONT, R.E.; BROCKS, L.; EIKELENBOOM, G.:

Muscle fibre type and meat quality. Meat Sci. 49 (1998), 219-229

KLOSOWSKA, D.; KURYL, J.; ELMINOWSKA-WENDA, G.; KAPELANSKI, W.; WALASIK, K.; PIERZCHALA, M.; CIEZLAK, D.; BOGUCKA, J.: An association between genotypes at the porcine loci MSTN (GDF8) and CAST and microstructural characteristics of $\mathrm{m}$. long.lumborum : a preliminary study. Arch. Tierz. 48 (2005), 50-59

LAWRIE, R.A.: Lawrie's Meat Science. $6^{\text {th }}$ edtition. Woodhead Publishing Limited, Cambridge, England. (1998)

LEE, S.O.; MIN, J.S.; KIM, I.S.; LEE, M.:

Physical evaluation of popped cereal snacks with spent hen meat. Meat Sci. 64 (2003), 383-390

LENGERKEN VON, G.; MAAK, S.; WICKE, M.:

Muscle metabolism and meat quality of pigs and poultry. Veterinarija Ir Zootechnika. T. 20 (2002), 82-86

LEOTHARAKUL, A.; SOPONJIT, S.; SAITONG, S.:

Selection and improvement of Maehongson native chicken for raising in up land of Thailand: Growth performance and genetic parameter, in: Proceedings of the Royal Project Annual Conference. Chiang Mai, Thailand (2002), 394-404 [in Thai]

MORRISON, W.R.; SMITH, L.M.:

Preparation of fatty acid methyl esters and dimethylacetals from lipids and boron fluoride-methanol. J. Lipid Res. 5 (1964), 600-608

NOWSAD, A.A.K.M.; KANOH, S.; NIWA, E.:

Thermal gelation characteristics of breast and thigh of spent hen and broiler and their surimi. Meat Sci. 54 (2000), 169-175 


\section{NRC (NATIONAL RESEARCH COUNCIL):}

NUTE, G.R.:

Nutrient Requirements of Poultry, $9^{\text {th }}$ rev. ed. National Academic Press, Washington DC (1994)

Sensory assessment of poultry meat quality, in: Poultry Meat Science. R. I. RICHARSON and G. C. MEAD ed. Poultry Science Symposium Series, Wallingford (1999), 369-376

PETER, W.; DÄNICKE, S.; JEROCH, H.:

Einfluss der Ernährungsintensität auf den Wachstumsverlauf und die Mastleitung französischer „LABEL“ Broiler. Arch. Tierz. 40 (1997), 69-84

QUENTIN, M.; BOUVAREL, I.; BERRI, C.; BIHAN-DUVAL, E.L.; BAÉZA, E.; JÉGO, Y.; PICARD, M.:

Growth, carcass composition and meat quality response to dietary concentrations in fast-, medium- and slow-growing commercial broilers. Anim. Res. 52 (2003), 65-77

ROSSELL, J.B.:

Measurement of rancidity. Pages 22-53 in Rancidity in Foods J.C. ALLEN and R.J. MAMILTON ed. Blackie Academic \& Professional, London (1994)

SAS:

Institute Inc., SAS/STAT Software: Changes and Enhancements, Release 8.2, Cary, NC. (2001)

SHAARANI, S.M.; NOTT, K.P.; HALL, L.D.:

Combination of NMR and MRI quantitation of moisture and structure changes for convection cooking of fresh chicken meat. Meat Sci. 72 (2006), 398-403

SHAHIN, K.A.; ELAZEEM, F.A.:

Effects of breed, sex and diet and their interactions on carcass composition and tissue weight distribution of broiler chickens. Arch. Tierz. 48 (2005), 612-626

STEEL, R.G.D.; TERRIE, J.H.:

Principles and Procedures of Statistics. A Biometric Approach. $2^{\text {nd }}$ ed. McGraw-Hill, New York. USA (1980)

WATTANACHANT, S.; BENJAKUL, S.; LEDWARD, D.A.:

Microstructure and thermal characteristics of Thai indigenous and broiler chicken muscles. Poult. Sci. 84 (2005), 328-336

YANG, N.; JIANG, R.-S.:

Recent advances in breeding for quality chickens. World's Poult. Sci. J. 61 (2005), 373-381

Received: 2007-11-13

Accepted: 2008-03-04

Authors:

Assoc. Dr. SANCHAI JATURASITHA*

Ms. AUTCHARA KAYAN

Department of Animal Science

Faculty of Agriculture

Chiang Mai University

Chiang Mai

Thailand 50200

Prof. Dr. MICHAEL WICKE

Institute of Animal Breeding and Husbandry

Georg-August-University of Göttingen

Albrecht-Thaer-Weg 3

37075 Göttingen

Germany

*Corresponding author

email: ja.sanchai@gmail.com 